\title{
REVIEW
}

\section{Marine epibiosis. I. Fouling and antifouling: some basic aspects}

\author{
Martin Wahl \\ Zoologisches Institut, Universität Kiel, Olshausenstr. 40-60, D-2300 Kiel, Federal Republic of Germany
}

\begin{abstract}
In the marine environment any solid, exposed undefended surface will become fouled. Similarly, fouling may effect numerous species which are able to tolerate a certain degree of epibiosis. In contrast, many others actively maintain their body surface clean of epibionts ('antifouling'). This paper illustrates aspects of the epibiosis/antifouling complex and discusses the omnipresence of fouling pressure, the first stages in the establishment of a fouling community, the benefits and disadvantages of epibiosis for both epi- and basibionts, and possible antifouling defense adaptations.
\end{abstract}

\section{INTRODUCTION}

This paper is intended as an introduction to the field of marine epibiosis. As the literature on the subject is considerable, a full analysis or discussion of all the available information has not been attempted. The result is an admittedly incomplete picture of our current understanding of this problem. Several interesting aspects such as larval settlement behavior population dynamics, interactions between fouling organisms and coevolution between epi- and basibionts, etc. have not been considered.

Epibiosis is a typically aquatic phenomenon Although occasionally encountered in terrestrial environments, on land it is generally restricted to humid climates and to a few hardy epibiotic organisms, the latter most often adapted to cope with lack of water and/or nutrients (Lüttge 1985). The reason for the difference between these 2 environments lies in the density difference between the 2 media: air rarely plays the role of a nutrient (dissolved or particulate) vector in the same way that water does, while evaporation, desiccation, etc. are unknown problems in subtidal depths of the sea. As substrate-bound nutrient uptake is of secondary importance to most sessile hardbottom organisms, all solid surfaces represented possible settlement sites for algae and sessile animals Furthermore, the high viscosity of the medium (water) in combination with the relatively low specific weight of immersed organisms render attachment crucial in turbulent habitats. Clearly therefore, a sessile, filterfeeding mode of life is more favourable in an aquatic environment than in the terrestrial milieu. In consequence, epibiosis and fouling are extremely common phenomena in the sea, and unoccupied hard substrata may often become a limiting factor in an otherwise favourable environment.

Before treating marine epibiosis in more detail it seems appropriate to define some of the more important terms as they will be used in this paper.

Antifouling: Strategies used by potential basibionts to limit or prevent colonization by epibionts

Basibiont: Substrate organism, which is host to the epibiont.

Epibionts: Organisms growing attached to a living surface. Trophic exchange with the substrate organism, if present, is facultative. The terms basibiont and epibiont describe ecological roles. They are rarely species-specific. Numerous sessile organisms may live either as basibiont or as epibiont, or both simultaneously (in an epibiosis of the second or third degree) according to circumstances.

Epizoans: Sessile epibiotic animals.

Epiphytes: Epibiotic plants (mostly algae).

Epibiosis: Non-symbiotic, facultative association between epibionts and basibiont. 
Fouling: Colonization process of a solid surface (living or dead).

In the following the phenomenon of marine epibiosis will be examined from different angles: colonization of surfaces, the ecological importance of epibiosis, resulting gains and losses for epi- and basibionts, respectively, and the possible behavioral adaptations of potential basibionts subjected to fouling pressure.

\section{FOULING SEQUENCE MODEL}

The establishment of fouling communities on a wide variety of substrata has been investigated thoroughly and the resulting literature is vast. Generally, colonization processes have been" studied on inert surfaces. Extrapolations to living substrata should be made with care, even when the few investigations of fouling sequence on living surfaces which have been conducted (e.g. Novak 1984) show similar results.

In most cases the initial steps of this extremely complex process seem to follow a basic pattern which is nearly independent of the type of substratum, the geographical region or the colonizing species studied (Characklis 1981, Corpe 1982, Baier et al. 1983, Bakus et al. 1986).

The fouling sequence described hereafter should be considered as a model, with all the simplifications and limitations that entails. Thus, in any particular situation 1 or even 2 of the sequential links may be missing, and the time scales given here are merely indicative.

Colonization of a new surface is composed of 4 phases constituting an overlapping time sequence: biochemical conditioning, bacterial colonization, unicellular and, finally, multicellular eukaryont fouling (Fig. 1). In the course of this sequence the prevailing processes change progressively from purely physical to predominantly biological - even though the influence of near-bottom hydrodynamics, for example, can be important at the level of larval settlement (Butman 1987)
Biochemical conditioning describes the adsorption of dissolved chemical compounds (mostly macromolecules) to any surface in the first moments after contact with natural seawater. This instant (hereafter simply called 'immersion') may be the extrusion of a growing seagrass blade from its sheath, the appearance of a new crustacean carapace after moulting, the emergence of a fresh rock surface after breakage or the experimental immersion of a glass slide, etc.

The concentration process of organic molecules at interfaces (solid/liquid, liquid/gas) is purely physical and 'spontaneous' (Baier 1984). As this event reduces the randomness of molecular distribution, the accompanying loss of entropy must be compensated by a notable diminution of the total free energy of the system. This latter phenomenon is apparently due to the replacement of a high energy solid/liquid interface by a lower energy organic layer. (For a detailed analysis see Dexter 1976, 1978, Dexter \& Lucas 1985.)

The adsorption of macromolecules begins within seconds after immersion and a dynamic equilibrium is reached within a few hours. Substrata originally exhibiting a wide range of surface free energy (garmma) values seem to adsorb the same kind of macromolecules (mostly glycoproteins, proteoglucans and polysaccharides) from seawater. By this process their physical and chemical surface properties converge so that low-energy ('hydrophobic') surfaces experience an increase and high-energy ('hydrophilic') surfaces a decrease of their gamma-values. The center of this convergence seems to be a gamma-range between 30 and 40 dyne $\mathrm{cm}^{-1}$ (Baier 1981).

Whilst the chemical composition of the adsorbing film is fairly independent of the initial surface free energy of the substratum, this property exerts a major influence on the binding strength and the spatial structure of the film: while the adsorbed film is compact and firmly attached at high and very low gamma-values, on medium range substrata (20 to 30 dyne $\mathrm{cm}^{-1}$ ) it shows a flocculent, loosely bound aspect (Baier 1981). Interest-

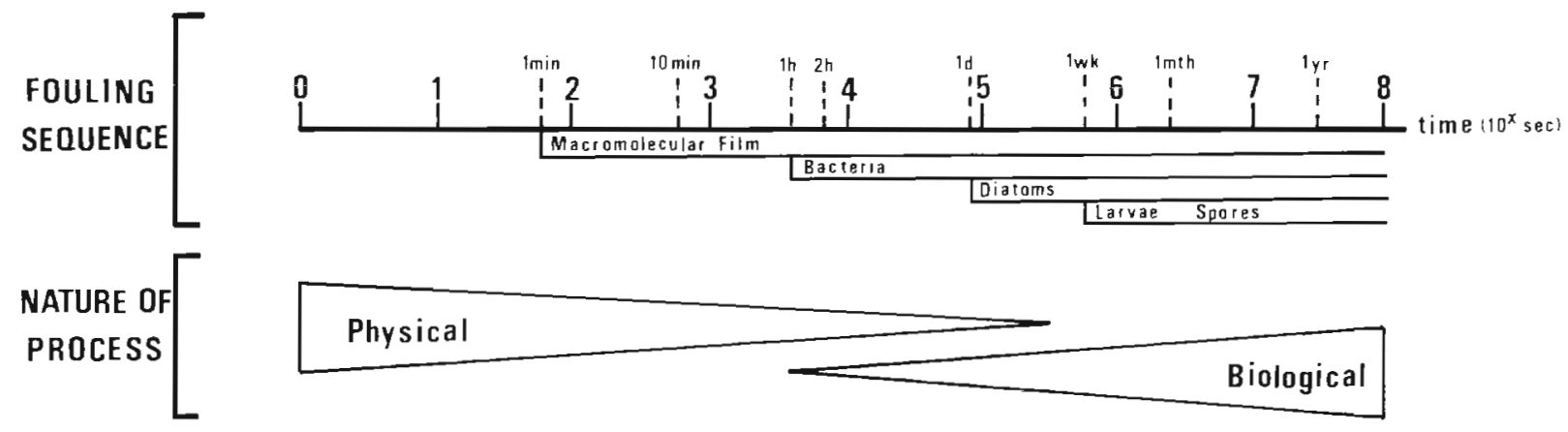

Fig. 1 Highly schematized colonizing sequence leading to the establishment of a fouling community. The nearly instantaneous adsorption of macromolecules is followed several hours later by prokaryote fouling. Diatoms and protozoa typically settle from the second day onward. Larvae and algal spores follow with a lag of one to several weeks (according to latitude, season, etc.) 
ingly, these low-adsorption surface free energies coincide with the non-polar component of water surface tension (ca 22 dyne $\mathrm{cm}^{-1}$ ). This correlation may play a rôle in antifouling defense (see below).

It is notable that the described course of biochemical conditioning is almost identical in quite different environments such as seawater, the human oral cavity, marine cooling systems, the vertebrate circulatory system, the uterus and interstitial body fluids (Baier 1981) The common denominator in all these cases is that the medium is a dilute, salty, aqueous solution of proteins and sugars.

Bacterial colonization of a surface is composed of a reversible approach phase ('adsorption') and a nonreversible attachment phase ('adhesion'). Like the first step in the colonization sequence (biochemical conditioning) bacterial adsorption is essentially governed by physical forces: Brownian motion, electrostatic interaction, gravity, Van-der-Waal forces (Dexter 1976, 1978, Fletcher \& Loeb 1979, Walt et al. 1985; Fig. 2). The behavior of small bacterial cells has repeatedly been compared to that of colloid particles (Marshall 1972, Characklis 1981), whose large-scale transport $(\mathrm{km}, \mathrm{m}, \mathrm{cm})$ is a consequence of currents and turbulence, while their small-scale movement ( $\mathrm{mm}, \mu \mathrm{m})$ is essentially due to Brownian motion (Lavenda 1985) and - for motile bacterial forms - flagellar propulsion.

When approaching a surface, any particle first encounters the hydrodynamically inert 'viscous layer', a ca 40 to $100 \mu \mathrm{m}$ thick, physically well-structured layer of $\mathrm{H}_{2} \mathrm{O}$ molecules which films all solid surfaces in water. Only after penetrating this 'mantle' by a particular form of microturbulence ('downsweeps'), bacterial motility or diffusion, can physical forces between bacterium and surface begin to act. When both bacterial cell surface and adsorbed macromolecular film are predominantly negatively charged (Marshall 1972, Corpe et al. 1976, Wicken 1985) the antagonistic forces of electrical repulsion and Van-der-Waal attraction tend to immobilize the cell at a distance of 3 to $20 \mathrm{~nm}$ from the surface (Fletcher \& McEldowney 1984).

This electrostatic barrier may be bridged by the production of polysaccharide fibrils (mostly glucose and fructose). These are anchored to their chemical counterparts in the macromolecular film by lectins or divalent cations $\left(\mathrm{Ca}^{++}, \mathrm{Mg}^{++}\right.$) (Costerton et al. 1978). A subsequent enzymatic shortening of the fibrils pulls the cell toward the surface (Fletcher \& McEldowney 1984). With diminishing distance, Van-der-Waal forces accelerate the approach (Adamson 1982, Wicken 1985). With the establishment of covalent bonds between the bacterial glycocalix and the macromolecular film the adsorption phase blends into the adhesion phase.

Similar attachment mechanisms have been described for yeasts (Douglas 1985), unicellular algae (Tosteson et al. 1983), spores (Fletcher et al. 1984) and polychaete larvae (Kirchman et al. 1982).

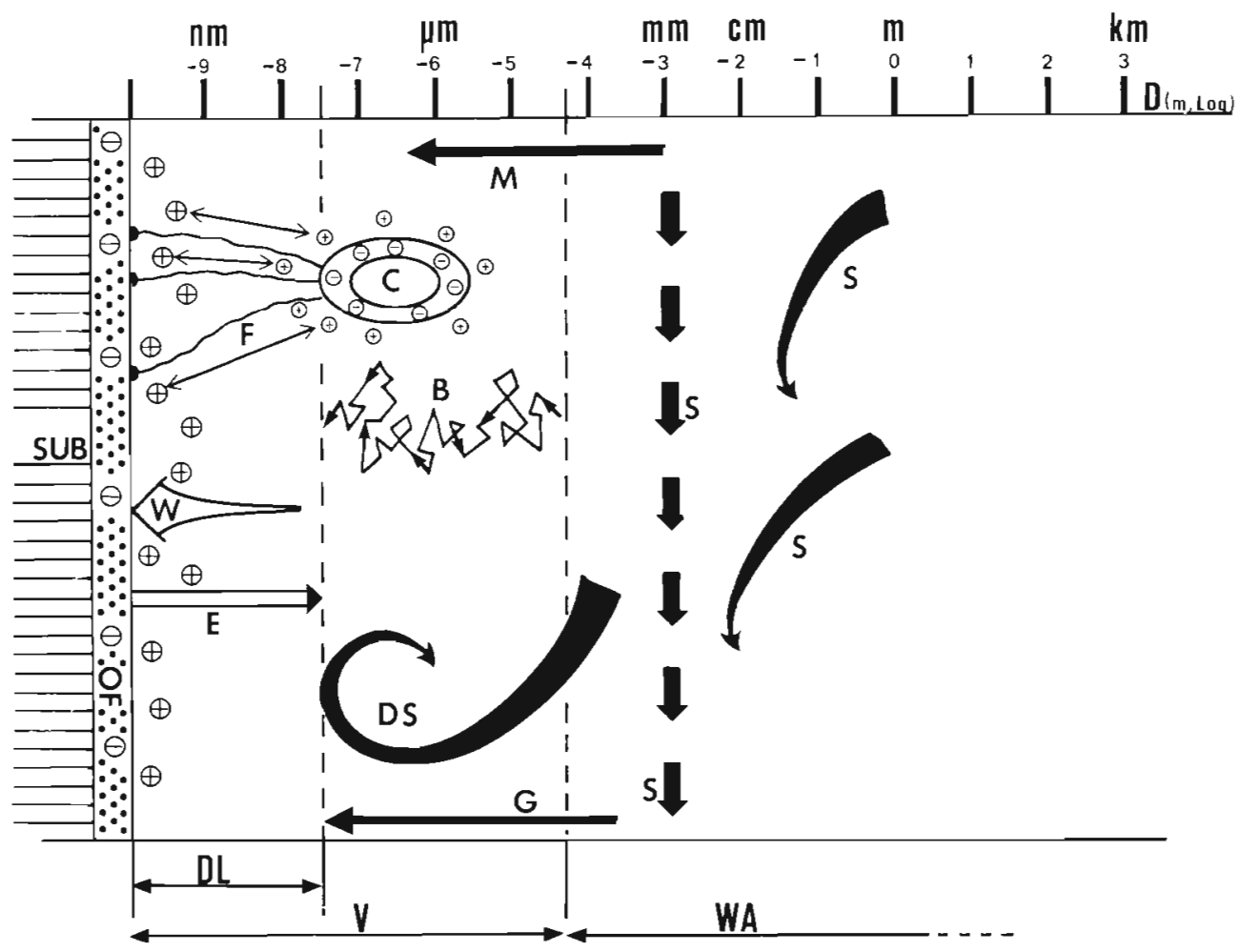

Fig. 2. Bacterial adsorption: dominating forces as a function of distance from the previously adsorbed macromolecular layer $\mathrm{B}$ : Brownian motion; $\mathrm{C}$ : bacterial cell; DL: electrostatic double layer; DS: downsweep (microturbulence) E: electrostatic repulsion; $F$ : bacterial fibrils anchored to adsorbed macromolecules; G: gravity (for a horizontal surface); $M$ : bacterial motility; OF: organic film of adsorbed macromolecules; S: currents and macroturbulence; SUB: substratum; $V$ : viscous boundary layer; $W$ : Van-derWaal's forces; WA: water body 
Not all bacterial forms adsorb with the same ease. For example:

(1) A (locally) hydrophobic cell surtace (Marshall 1972, Fletcher \& Loeb 1976. Fattom \& Shilo 1984, Rosenberg 1984, Paul \& Jeffrey 1985, Wicken 1985) thermodynamically favors the wetting of a surface by the cell, especially when the conditioned substratum's gamma values are lower than those of water (Rosenberg 1981, Absolom et al. 1983, Pringle \& Fletcher 1983).

(2) Pioneer forms are often rod-shaped and adsorb vertically thus reducing the electrical repulsion (Lupton \& Marshall 1984).

It is the biological characteristics and physiological requirements of different bacterial forms which determine the colonizing succession within a bacterial fouling community. Morphologically discriminated, rodshaped pioneers generally arrive first, followed by coccoid and, finally, stalked and filamentous forms (Marshall et al. 1971, Corpe 1972). This growing bacterial lawn, composed of dead and living cells and their secreted 'slime', together with the macromolecular film constitutes the so-called primary film (biofilm, slime film). During this microfouling phase the properties of the substratum/water interphase again change drastically.

Bacterial colonization begins about an hour after immersion. A steady state is rarely reached since the microbial community evolves continuously due to succession, physical disturbance, competition, predation. etc. (Little 1984)

Colonization by unicellular eukaryonts comprises the arrival of yeasts, protozoa and diatoms, with a clear quantitative dominance of the latter (Marshall et al. 1971, Corpe 1972, Cuba \& Blake 1983). This phase usually begins several days after immersion, and here, as in the case of bacteria, we may distinguish between pioneer and late successional forms (O'Neill \& Wilcox 1971, Ferreira \& Seeliger 1985).

Benthic diatoms attach by mucus secretion (Cooksey et al. 1984, Ferreira \& Seeliger 1985), may densely cover wide substratum areas, and contribute significantly to the chemical/biological evolution of the substratum. While in the majority of observed events diatom colonization was always preceeded by bacterial lawn growth (Little 1984), there may be exceptions (Sieburth \& Tootle 1981, Maki et al. 1988).

Protozoan colonizers either belong to the sessile filter feeding forms or are motile predators of microorganisms (bacteria, yeasts, diatoms, other protozoa). The latter, because of their motility, are not considered to be true epibionts as defined above. Neither are the colonizing yeasts which depend trophically upon their substratum. These are reported to play an important part in the transformation and concentration of nutrients from older (dying or dead) thalli and leaves (Cuomo et al. 1985).

Colonization by multicellular eukaryonts. Depending on the biological activity of the waters, one to several weeks after immersion the substratum bears a highly differentiated and 3-dimensionally structured microbiotic community. Several days to weeks after biochemical conditioning the last and longest phase of colonization begins with the settlement of meroplanktonic larvae and algal spores. This overlaps with the continued recruitment to and evolution of the microepibiotic community.

This stage of the fouling process has been repeatedly and thoroughly described and I will confine myself to citing some key articles on the subject: Meadows \& Williams (1963), Christie (1973), Crisp (1974), Sutherland (1974), Jackson (1977), Osman (1977), Sutherland \& Karlson (1977), Characklis (1981), Evans (1981), Kirchman \& Mitchell (1981), Brewer (1984), Costlow \& Tipper (1984), Fletcher \& Baier (1984), Fletcher et al. (1984), Morse (1984), Hadfield (1986), Butman (1987).

After these 4 major settlement steps, the fouling community evolves continuously by mechanisms such as disturbance, facilitation, inhibition, tolerance, etc. (Connell \& Slatyer 1977, Bakus et al. 1986).

\section{Chronologically or causally determined sequence?}

If the model presented above proves to be of general validity then we could ask what the underlying control mechanisms may be. I believe there are 2 mutually compatible, possible explanations for the surprising constancy of the fouling sequence.

First, one can argue that the sequential attachment of colonizing elements (macromolecules $\rightarrow$ bacteria $\rightarrow$ diatoms, protozoans $\rightarrow$ larvae, spores) simply mirrors the specific 'availability' of the foulers. In natural seawater dissolved macromolecules are omnipresent and show minimal physical inertia. To a lesser extent bacteria also occur in high densities (especially on seston). Their short generation times, high genetic variability and mutability facilitate a fast and adaptable colonization of the most varied substrata. The unicellular eukaryonts, while 'slower' and less numerous than bacteria, exhibit a more flexible and 'opportunistic' behavior than the biologically more inert and generally rarer larvae and spores. Furthermore, the presence of the latter in the plankton is usually restricted to the reproductive period of the species concerned.

Thus, the observed fouling sequence might merely reflect average abundance and behavioral flexibility, i.e. the availability of the different colonizing forms at the moment of immersion of a new substratum. On the other hand, the presence of causal links between suc- 
ceeding stages within the sequence has been suggested repeatedly.

The macromolecular filming of surfaces causes a convergence of initially often extreme surface free energy values (see above). Furthermore, the bound glycoproteins and proteoglucanes may offer suitable linkage sites for the attachment of bacteria (Fig. 2; Costerton et al. 1978, Lupton \& Marshall 1984). Conversely, a weakly bound biochemical film (due to initial gamma values between 20 and 30 dyne $\mathrm{cm}^{-1}$, see above) severely impairs the adhesion of succeeding colonizers (Goupil et al. 1973, Dexter 1976, 1978, Mitchell \& Kirchman 1984).

By the process of thermodynamically motored selective adsorption most interfaces in the sea (solid/liquid, liquid/gas) act as nutrient traps by sharply concentrating energetically valuable compounds such as proteins and sugars (Booth \& Hoppe 1985). Chemotactic bacteria are attracted to this nutrient pool (Characklis 1981) which may serve as a major food source to most attaching heterotrophic bacteria. Thus, biochemical conditioning may promote bacterial colonization.

It has been suggested that similar factors link the next 2 phases. Several authors believe that the severalday lag in diatom colonization (Marshall et al. 1971 O'Neill \& Wilcox 1971) reflects a 'conditioning phase of the substratum by biochemical filming and bacterial activity (e.g. Corpe 1972, Holmes 1986). Most benthic diatoms adhere either by secreted polysaccharides or by protein or lectin binding sites which 'stick' to thermodynamically adsorbed or bacterial sugar units better than they do to a naked surface (Tosteson \& Corpe 1975, Tosteson et al. 1983, Mitchell \& Kirchman 1984). Furthermore, the metabolic activity of previously attached bacteria may improve the microenvironment through vitamin production (Lynch et al. 1979), $\mathrm{N}_{2}$ fixation (Goering \& Parker 1972), detoxification of the surface (Saroyan 1968), etc.

Finally, the settlement selectivity of larvae (and to a much lesser extent that of spores) has been investigated for a variety of species. A comprehensive overview is given by Crisp (1984). Substratum 'choice' is influenced not only by physical factors such as light, color, gravity, pressure and turbulence but also by surface characteristics that may be related more closely to the biochemical, bacterial and diatom colonization phases, namely surface microtexture, wettability, electrostatical properties, $\mathrm{pH}$, chemical settlement inducers, bacterial and diatom exudates (Meadows \& Williams 1963, Crisp 1974, Brancato \& Woollacott 1982, Morse 1984, Huang \& Boney 1985, Bakus et al. 1986, Wethey 1986, Chabot \& Bourget 1988). Whilst larvae of most species will eventually settle on physically clean surfaces when the alternative would be an intolerable delay of metamorphosis, numerous larvae (and spores?) preferentially attach to substrata that have already been conditioned by the first 2 or 3 colonizing phases (Mitchell \& Kirchman 1984, Woollacott 1984, Kitamura \& Hiroyama 1987). Crisp (1984) speaks of a 'predelection for filmed surfaces', yet this statement is not without contradiction. Sieburth \& Tootle (1981) describe diatom colonization of artificial substrata in the absence of a bacterial film, Maki et al. (1988) have observed that biofilms formed by certain bacterial strains inhibit the settlement of barnacle larvae and Mihm et al. (1981) found that a bacterial film may promote or inhibit bryozoan larval settlement depending on initial surface tension of the substratum. Huang \& Boney (1985) showed that a previously formed diatom film favored settlement of fucoid sporelings, while it impeded attachment of several other algae.

Clearly then, the notion that a given fouling phase will have a promoting effect on the following one(s) is not unanimously accepted (Little 1984) and is certainly not yet proven (Bakus et al. 1986).

It is possible that the apparent constancy of the fouling sequence is a result of the factors 'colonizer availability' and 'progressive surface conditioning' acting synergistically, however the relative importance of these remains to be established.

\section{ECOLOGICAL CONSEQUENCES OF EPIBIOSIS}

The threat of fouling is omnipresent and the list of fouled species is long. Several hundred epibiotic associations have already been noted (e.g. Harlin 1980, Ingle 1983, Novak 1984, D'Antonio 1985, Lewis et al. 1985, Wahl 1987). Regrettably, in most instances it is not possible to retrace a posteriori whether a given epibiont in a reported association was found exclusively, regularly or exceptionally, in high or in low abundance on a particular host.

On the other hand, a great number of marine organisms do keep their body surface largely clean of epibionts - though it is unlikely that there are many sessile species which are not occasionally (seasonally, locally, or on the level of 'weakened' individuals) subject to epibiosis.

Any potential basibiont, i.e. the majority of sessile, relatively long-lived organisms, must either defend itself against fouling or tolerate epibiosis. Defense may be costly (see below), while epibiosis entails both benefits and disadvantages for epi- and basibiont.

\section{Epibionts: benefits}

- In densely populated marine environments where competition for space is high the advantage of coloniz- 
ing an as yet unoccupied surface is probably the dominant reason for the fouling of living substrata (Linskens 1963a, Ryland 1974, Novak 1984, Witman \& Suchanek 1984, D'Antonio 1985). For most meroplanktonic larvae settlement is a prerequisite for successful metamorphosis. Other colonizers such as bacteria, benthic diatoms and sporelings proliferate more rapidly or exciusively when fixed.

- Laterally growing (colonial) animals and plants and those reproducing asexually by stolons or fission benefit from an epibiotic habitat by having an advantageous starting position for colonization of newly emerging surface created by basibiont growth (Oswald $\&$ Seed 1986)

- Epibiotic settlement frequently implies a hydrodynamically favorable position (Linskens 1963a, Keough 1984, 1986, Oswald \& Seed 1986) as water movement increases with distance away from a solid surface (Butman 1987). Better flow ensures higher nutrient supply and a more efficient evacuation of wastes. At the same time the flexible nature of a living substratum can compensate for the dangers of increased turbulence (Linskens 1963a, Riedl 1971).

- A more exposed habitat improves irradiation (Brouns \& Heijs 1986) which may be a photosynthesislimiting factor in the lower strata of dense fouling communities, at greater depths or in turbid waters.

- The nutritional conditions are particularly favourable for epibionts, because most immersed surfaces act as nutrient traps which enhance microbial growth. Furthermore, many epibionts may benefit from the exudation of metabolites by the basibiont, especially on algal substrata (Linskens 1963a, Harlin 1973. Penhale 1977, Kong \& Chan 1979, Lynch et al. 1979, Mazure \& Field 1980, Booth \& Hoppe 1985, Harrison \& Durance 1985, Oswald \& Seed 1986). 'Meal-sharing' in the anemone/hermit crab association is an example of this commensalism.

- Filter-feeding epibionts possibly profit from the nutrient currents created by certain hosts (Ryland 1974, Laihonen \& Furman 1986).

- Occasionally, epibionts seem to be protected by the defensive shield of certain basibionts ('associational defense'; Hay 1986, Young 1986).

To conclude this incomplete list, a mention should be made of the free transport offered by motile basibionts which may improve nutrient conditions (site change, currents) and facilitate dispersal and gene-flow among epibiont populations.

\section{Epibionts: disadvantages}

- One major problem for epibionts is the unstable character of their living substratum (Filion-Myklebust
$\&$ Norton 1981, Novak 1984). The moment of disaggregation of a basibiont individual by natural mortality, physical disturbance or predation is completely unpredictable. This instability is further aggravated by specific morphological changes of the substratum during a basibiont's life cycle. These include growth and shrinking, fission and fusion, shedding of fruiting bodies and leaves, moulting, etc. Naturally, the stability of a substratum is a relative notion: the longer the maturation time of an epibiont species, the greater its requirements regarding the longevity of the substratum.

Another aspect of the instability of living substrata is illustrated by the fluctuations of physiological activity of the basibiont. Production and exudation of metabolites (wastes, nutrients, toxins, etc.) by numerous organisms may fluctuate temporally with season, predation pressure, developmental stage and biological cycles of the individual and may also vary spatially with habitat and among different organs of the same individual. Successful colonizers must either have a large tolerance range or settle during phases when - or on organs where - the composition and quantities of exudates are not harmful.

- Trophic competition between basi- and epibiont is of course possible (Novak 1984, Bronmark 1985), but should usually act in favor of the epibiont due to its 'upstream' position.

- One of the greatest hazards in an epibiont's life is the danger of falling victim to predators of the substrate organism (Oswald et al. 1984, Cuomo et al. 1985).

- Living on motile substrata entails the peril of physiological stress due to potentially drastic environmental changes during the basibiont's migrations. An extreme example is represented by the epibiotic community on the shell of the turtle Caretta caretta caretta (Caine 1986), which must tolerate transitions between oceanic, coastal, limnic and terrestrial conditions.

The benefits and dangers of life on a living substratum may compensate one another - numerous sessile organisms settle with apparently perfect indifference on living or non-living surfaces (Cattaneo 1983, Cattaneo \& Kalff 1978, 1979, Harlin 1973, Horner 1987, Novak 1984).

\section{Basibiont: benefits}

- It has been suggested that energy flow between epibiotic partners may occasionally come to the benefit of the host (Linskens 1963a, Harlin 1973). It is thought that association with microorganisms may sometimes improve the basibiont's supply of vitamins (Lynch et al. 1979) and/or nitrogenous compounds (Goering \& Parker 1972) or provide a favorable physical microenvi- 
ronment at the surface which facilitates nitrogen uptake by the basibiont (Lupton \& Marshall 1984). Equally, the substratum organism may benefit from the exudates of epibiotic diatoms and macroalgae. Usually, nutrient flow (if any) is indirect and does not pass across the contact area between epibiont and basibiont, but through the surrounding seawater (e.g. Harlin 1973).

- Frequently, epibiotic cover can play a protective role. Thus, water-retaining epibionts are reported to slow down desiccation of intertidal organisms (Penhale \& Smith 1977) during low tide; others serve as a camouflage to their host (Stoecker 1978, Witman \& Suchanek 1984). As prey is often identified by chemical cues, the exudations or surface properties of an epibiotic cover may act as chemical camouflage (Fishlyn \& Phillips 1980, Feifarek 1987). Well-defended epibionts (e.g. Cnidaria, Porifera, Cyanobacteria) may provide free protection to their host (e.g. Christophersen 1985 , Bakus et al. 1986, Barkai \& McQuaid 1988; 'extrinsic defense': Dyrynda 1986, Feifarek 1987).

- The example of hydrophobic, drag-reducing bacteria on the skin of fast-swimming fish (Sar \& Rosenberg 1987) illustrates how epibiosis can modify surface properties to the benefit of the basibiont.

\section{Basibiont: disadvantages}

Fouling by calcareous epibionts (e.g. Corallinaceae, Bivalvia, serpulid and spirorbid Polychaeta, many Bryozoa) causes an increase in weight (Dixon et al. 1981, Cuomo et al. 1985, Oswald \& Seed 1986), and therefore reduces buoyancy.

- Rigid, crustose epibiotic forms, such as Bryozoa reduce the elasticity of the substratum, hindering both motion and flexibility (Dixon et al. 1981) and increased brittleness enhances breakage in high turbulence environments.

Erect, branching and/or rough epibionts sometimes lead to a substantial increase in surface friction (Dixon et al. 1981, Keough 1984, D'Antonio 1985, Caine 1986), which may result in dislocation of basibionts in highvelocity habitats (Witman \& Suchanek 1984).

- Mechanical anchoring of larger epibionts accasionally damages soft basibiont surfaces (Dixon et al. 1981, Witman \& Suchanek 1984\}.

- Drastic changes of $\mathrm{pH}$ and redox conditions by certain microepibionts (Terry \& Edyvean 1981) may attack chemically sensitive body surfaces of the basibiont.

- Epibiotic shading of plant surfaces is reported to reduce incoming light by up to $80 \%$ (Bulthuis \& Woelkerling 1983, Sand-Jensen \& Revsbech 1987). Thus, photosynthesis may for example be reduced below the compensation point to the extent that the negative energy budget results in the mortality of whole seagrass populations (Sand-Jensen 1977, Bulthuis \& Woelkerling 1983).

- A basibiont's transcutaneous uptake or excretion of nutrient salts, dissolved organic matter, ions and/or gases may be affected by epibiosis, the impact being strongly dependant on the biology of the organism concerned. Animals with thick outer skeletons and which exchange most compounds through an internal filtering apparatus, like the tunicate Microcosmus or many bivalves, tolerate epibiosis more easily than seagrasses which undergo photosynthesis and osmoregulation in the blades (Jagel.s 1973), and take up nutrient salts via the roots. Seagrasses, however, suffer less from the epibiotic insulation effect than algae, where all transfer processes pass through the thallus surface.

- Competition for nutrients (particulate, dissolved and gaseous) between epibiont and host has often been postulated (Stoecker 1978, Novak 1984, Libes 1986, Sand-Jensen \& Revsbech 1987). When the epibiotic partners exhibit the same trophic requirements, water reaching the basibiont may already be partially depleted after its passage through the 'epibiotic filter'.

As epibionts may fall victim to predators of their substratum, so may basibionts suffer from damage due to grazers preying on epibionts (Dixon et al. 1981, Oswald et al. 1984, Bronmark 1985, D'Antonio 1985).

On balance, it seems that epibiosis is generally unfavorable for the basibiont. However, because antifouling defense is probably costly - by inference from recent work on antiherbivory defenses (Coley et al. 1985, Coley 1986, Larsson et al. 1986, Fagerström 1989) - in energy-limited conditions toleration of fouling would release energy reserves normally invested in defense to growth or reproduction (Bazzaz et al. 1987 , Paul \& Van Alstyne 1988, Van Alstyne 1988). This may be especially so in the case of chemical defense.

In the words of Fagerstrom (1989) dcfense 'cost should be expressed as a loss in the relative growth rate of somatic tissue'. This is most evident when considering the substantial amounts of biomass lost through mechanical antifouling defenses such as mucus secretion, sloughing and moulting (analogous to the tributary defense', sensu Maiorana 1979).

According to Coley (1986), working on terrestrial plants, defense costs are the sum of (1) energy and nutrients consumed for defense production (and, therefore, lost to growth), (2) energy necessary for sequestering toxins away from active cell processes, (3) interference of some defenses with photosynthesis and (4) loss of the productivity of the tissue that could have been produced if it were not for defense. Even if we consider that some chemical defenses may be recycled, there is still an energetic loss during the necessary transformations 
'Producing defenses is up to twice as costly as is producing biomass' (Fagerström 1989), is a statement supported by the observation that under nutrient-deficient conditions the relative concentration of defensive compounds is reduced (Larsson et al. 1986). Finally, if defense were not metabolically expensive, there would be less reason for evolving inducible defenses (although the specific induction of antifouling defenses is yet to be investigated).

Thus, while the costs of antifouling defenses remain to be established, it seems highly improbable that this kind of protection, in contrast to antiherbivory defense, could generally be obtained without considerable energetic expense.

This section has shown that epibiosis can not be classified globally as either 'beneficial' or 'detrimental for either partner. Whether or not a living substratum is colonized will, in each individual case, depend on the relative importance of the parameters cited above in relation to the biology of the species concerned, environmental conditions, availability of free hard substratum, apparency (sensu Feeny 1976), individual fitness and certainly many more as yet undetermined factors.

\section{BASIBIONT REACTION PATTERNS TO EPIBIOSIS}

Sessile marine organisms are continuously exposed to bacteria, diatoms, spores and larvae which may be ready to settle. While the intensity of fouling pressure varies with season, latitude, depth and local ecological factors, any permanently exposed, non-defended surface will sooner or later become fouled.

Three major classes of adaptations to this situation have evolved: tolerance, avoidance and defense. These adaptations are not necessarily exclusive, definitive or global. Thus for a given organism several behavioral patterns may be combined and the adaptations adopted may vary with season, habitat, a species' biology, age and physiological stage and between different parts of the same individual and according to the immediate fouling pressure. Similarly the susceptibility of the species to fouling ('apparency' sensu Feeny 1976) and the potential epibiosis-induced damage to the species, individual or organ considered will play an important role.

In this context mention should be made of a type of 'defense parasitism' known from predator/prey investigations (Hay 1986) in which the co-occurrence of undefended species discretely intermingled with well-protected ones provides the former with some degree of protection. In the antifouling context an analogous phenomenon (extrinsic defense by selected epibionts) has been postulated (Dyrynda 1986).

\section{Tolerance}

Sedentary species which secrete mineral or organic outer shells, tubes, mantles, etc, will occasionally tolerate almost unrestricted colonization of these surfaces (e.g. some bivalvies, polychaetes, barnacles, tunicates). In addition, older and/or stressed individuals or those passing through a stage of physiological inactivity (Wahl 1987) may be heavily fouled.

Important prerequisites for the tolerance of epibiosis by a healthy individual are a prevailing indifference toward increased friction and weight and a physiologically inactive outer surface. Even when the whole organism seems to be covered by epibionts it is common that in active individuals the body's orifices (borders of shells, tubes and siphons) and external sense organs are maintained clean

\section{Avoidance}

This term will be used in its widest meaning and therefore will include the potential basibiont's avoidance of colonization by movement in space, time, or by dissimulation.

- Accelerated growth may produce tissue at a rate higher than the local fouling rate. In this manner a photosynthetically active zone may be maintained in the proximity of a plant's meristem, while the epibiotic cover increases along the age-gradient of the seagrass blade (Sand-Jensen 1977, Bulthuis \& Woelkerling 1983, Keough 1984, Novak 1984, Horner 1987) or algal thallus (Ballentine 1979, Mazure \& Field 1980, Russell 1983). A decreased concentration of antifouling compounds with tissue age caused by leaching and/or declining production (Harrison 1982, Johnson \& Mann. 1986a) and, on the other hand, changing hydrodynamic conditions along the same axis (Keough 1986, Horner 1987) may further increase the fouling gradient from young to old plant parts.

- Avoidance in time can be postulated, when a species instead of investing in antifouling defense diverts its energy reserves into enhanced reproduction (Maiorana 1979, Bazzaz et al. 1987, D'Antonio 1985).

- Crypsis represents the retreat of a species or a population into biologically less vulnerable habitats. In certain cases, such as when a species associates with another which secretes antifouling substances into the surrounding seawater (see 'associational defense') this adaptation could be interpreted as a protection against fouling

- Optical and chemical camouflage may be regarded as a kind of 'stationary' avoidance mechanism. Because colonizers in the marine environment rarely choose 'their' substratum visually, only the latter is of rele- 
vance here. As mentioned previously, the presence of specific epibionts on an organism's surface could deceive or deter further colonizers, thus helping to keep fouling of the basibiont at a tolerable level.

While, as an anti-epibiosis adaptation, avoidance does save a proportion of the energy which would otherwise be used for antifouling defense, it is not compatible with the biology and life-style of all marine organisms. Species that are slow-moving or sedentary, relatively long-lived and non-cryptic and which for morphological or physiological reasons may not tolerate epibiosis are those most likely to evolve defenses against fouling.

\section{Defense}

The evolution of protective innovations has been so productive that their consideration here will be restricted to the more outstanding instances. Details and examples may be found in the literature cited.

Regrettably, in comparison to the vast amount of information which is available on antipredator/antiherbivore defense, relatively little work has been done on antifouling protection. However, some of the underlying principles should be similar, and basic articles on defense in general have contributed to this list of antifouling adaptations (some of which are as yet untested).

The multitude of defense mechanisms may be divided into 3 groups: mechanical, physical and chemical defense.

\section{Mechanical defense}

- Fouling (especially macrofouling) may be hindered by special surface structures, such as spicules (e.g. Dyrynda 1986).

- An intense surface production of mucus may hamper the action of cilia and flagella, and because of its fluid character impede firm adhesion (Dyrynda 1986).

- The surface-bound cilia-driven migration of a mucus film might exert a cleaning 'windshield-wiper' function as described for the body surfaces of echinoderms (Barnes 1987), analogous to the processes on the filtering apparatus of Kamptozoa, Bivaivia and Tunicata.

- Epibiont removal can be effected by continuous or periodic surface renewal by means of mucus secretion as described for Cnidaria, Algae, Mollusca, Echinodermata, Tunicata, etc. (Lynch et al. 1979, Sieburth \& Tootle 1981, Targett et al. 1983, Krupp 1985), periodical shedding of the cuticula or epidermis known among algae and seagrasses, but also among sponges, Tunicata and stonefish (Jagels 1973, Mazure \& Field 1980, Myklebust \& Norton 1981, Sieburth \& Tootle 1981, Moss 1982, Russell \& Veltkamp 1984, Bakus et al. 1986, Johnson \& Mann 1986b, Wahl 1987, Barthel \& Wolfrath 1989); shell-switching of hermit crabs and moulting of Crustacea and Nematoda (e.g. Dyrynda 1986) and the scale-casting of sea turtles (Caine 1986), to name but a few examples.

- Similarly, friction between the sediment and the body surface of burrowing species or between water and fast swimmers may reduce the degree of fouling.

- Active removal of macroepibionts can be managed by the scraping of the surface with specialized appendages or by the picking activity of for example echinoderm pedicellaria or bryozoan avicularia and vibracularia (Dyrynda 1986)

The efficacy of these mechanisms is quite variable and depends on such factors as the proportion of the surface cleaned at a given time, the size of the colonizers, the local fouling pressure and the frequency of surface 'disturbance' (by a given mechanical defense device). Thus, moulting of adult crabs with a periodicity of several months is not likely to impede the establishment of a young epibiotic community, but may sporadically disrupt the fouling process. Continuous all-surface mucus sloughing on the other hand should be quite efficient. 'Picking' by avicularia, frequently reputed to be an antifouling defense, perhaps deters the largest colonizers such as larvae (but see review on avicularian functions by Winston 1984); however, it is certainly completely ineffective in respect to bacteria, diatoms and protozoa.

\section{Physical defense}

Research on the microfouling inhibiting properties of low-energy surfaces (20 to 30 dyne $\mathrm{cm}^{-1}$ ) (Corpe 1970 , 1972, 1982, Marshall et al. 1971, Dexter et al. 1975, Dexter 1976, Goupil et al. 1980, Baier 1981, Absolom et al. 1983, Baier et al. 1983, Fletcher \& Baier 1984, Busscher 1985) has found that adhesion is reduced on surfaces with a minimum of free ions in the outermost layer (highly methylated or fluorated compounds, nonpolar hydrocarbons, certain waxes, etc.).

At present, information on the physical surface properties of marine organisms is virtually non-existent. This may reflect a research gap rather than the actual absence of physical antifouling mechanisms in the sea. Techniques for measuring the wettability of cells and microorganisms (Gerson 1980, Gerson \& Akit 1980, Gerson \& Scheer 1980, Rosenberg et al. 1980, Rosenberg 1981, Absolom et al. 1983, Rosenberg 1984, Busscher 1985) and of reasonably smooth-surfaced 
macroorganisms (Wahl 1987) are now available, and the discovery of marine physical antifouling defense may simply be a question of time and effort. The existence of such defenses in aquatic organisms has been inferred by Linskens (1963b) and Ballentine (1979).

Several advantages would accrue from such a defense. Being conservatively surface-bound and therefore not suffering from loss, leaching or consumption, this mechanism is completely non-toxic and probably metabolically inexpensive. However, as lowenergy surface properties primarily reduce the adherence rather than the initial settlement of foulers, a high relative water velocity would be a prerequisite for this type of defense to work efficiently.

\section{Chemical defense}

The creation of unfavorable or toxic conditions at or immediately above an organism's surface is certainly a wide-spread antifouling adaptation in the marine environment.

- Extreme pH-values (basic or acid) in the immediate vicinity of the surface have repeatedly been postulated to play a part in epibiont deterrence by plants (Baker \& Orr 1986) and animals (Stoecker 1978, 1980). Stoecker's results on ascidian acid defense were questioned by Parry (1984) and Wahl (1987). If not coupled to normal metabolic excretion processes, as in the freshwater plants investigated by Baker \& Orr (1986), the maintainance of such extreme $\mathrm{pH}$-values in a chemical buffer such as seawater would consume considerable amounts of energy.

- Antifouling defense by means of surface-bound or exuded secondary metabolites (e.g. toxines) appears to be quite a common phenomenon (Stoecker 1980, Bakus \& Kawaguchi 1984, Cimino et al. 1985, Bakus et al. 1986, Ostrofsky \& Zettler 1986, Wahl 1987).

Whole-organism extracts have yielded a vast panoply of compounds (reviewed by Faulkner 1984a, b, 1986, 1987) with antibacterial (Sieburgh \& Conover 1965, Bell et al. 1974, Stoecker 1978, Lynch et al. 1979 Sieburth \& Tootle 1981, Harrison 1982, Wahl 1987), antifungal (Caccamese \& Azzolini 1979, Pesando et al 1979. Caccamese et al. 1980, 1981, Accorinti 1983 Pesando \& Caram 1984, Wahl 1987), antialgal (SandJensen 1977, Targett et al. 1983, Harrison \& Durance 1985, Wahl 1987), antilarval (Stoecker 1978, Rittschof et al. 1985, Keifer \& Rinehart 1986, Rittschof et al. 1986 Wahl 1987) and other, less well-defined fouling-impeding activities (Sieburth \& Conover 1965, Sieburth \& Tootle 1981, Moss 1982, Bronmark 1985. D'Antonio 1985, Johnson \& Mann 1986a, Gerhart et al. 1988).

Apparently, among species with a sessile mode of life, chemical antifouling defense by means of second- ary metabolites seems common, particularly so in modular organisms (plants, colonial animals etc.) (Dyrynda 1986).

\section{Extrinsic defense}

The hypothesis that a protective shield could be created by selected epibionts (probably in 'monoculture') has already been presented. As suitable substrata are in many instances identified chemically by potential colonizers, chemical exudations of epibionts masking those of the basibiont may mislead or deter further foulers. There is evidence demonstrating that chemical camouflage, due to epibionts, can function as a defense against predation (Fishlyn \& Phillips 1980, Wicksten 1983, Barkai \& McQuaid 1988).

Another form of extrinsic defense is the grazing of a basibiont surface by a specialized epibiont predators. This may contribute significantly to the reduction of the epibiotic cover (Bulthuis \& Woelkerling 1983, Cattaneo 1983, Breitburg 1984, D'Antonio 1985, Kairesalo \& Koskimies 1987, Wahl 1987). In some cases, fouled basibionts seem to attract grazers by exuded chemical signals (Bronmark 1985).

The list of defense mechanisms established here is necessarily incomplete. Nevertheless, it should demonstrate the broad spectrum of defenses against epibiosis which are possible. Most of the mechanisms may be and frequently are - combined to form a multifacetted antifouling adaptation, which covers efficiently the range of potential colonizers (Fig. 3). The advantage of combining overlapping mechanisms (e.g. sloughing and antilarval toxins) may lie in the reduced probability of the appearance in evolution of an apibiont preadapted to tolerate 2 or more defense mechanisms simultaneously.

At least in energy-limited environments, one criterion which should control the selection of an optimal combination of defense adaptations is the challenge of maintaining any epibiosis at a (species-specific) biologically tolerable level whilst incurring minimum defense costs.

\section{SUMMARY}

(1) All unprotected, apparent (sensu Feeny 1976), solid surfaces in the sea sooner or later become fouled.

(2) The frequently observable colonizing sequence (bacteria $\rightarrow$ diatoms $\rightarrow$ larvae, spores) is likely to be a result of the combined effects of differential colonizer availability and causal links between. some of the succeeding fouling stages.

(3) An epibiotic association creates a complex network of benefits and disadvantages between epibiont 


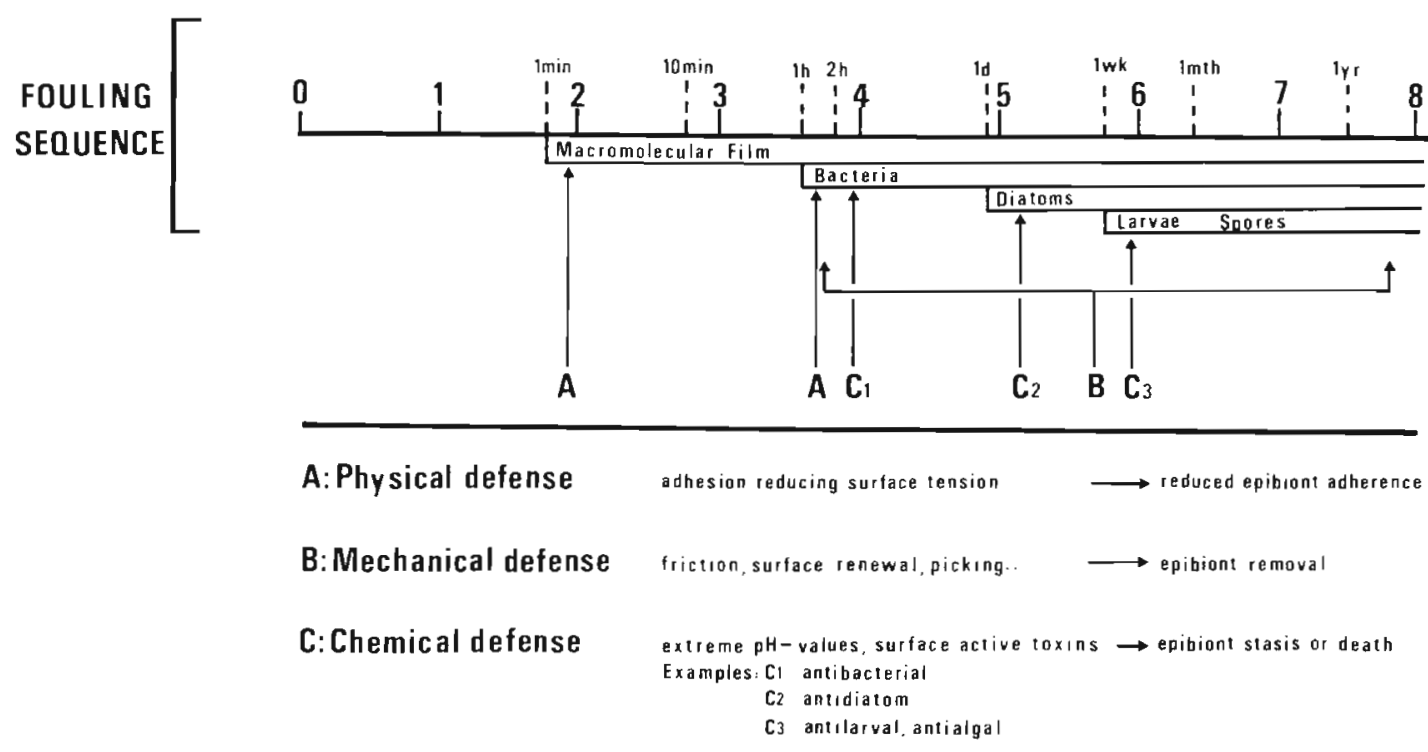

Fig. 3. Examples of antifouling defense adaptations with their respective target zones during the fouling sequence. For example while physical defense activity is limited to the processes of initial adsorption onto a young surface, sloughing may act at all levels

and basibiont. The relative importance of positive and negative effects is determined in each case by a multitude of species-specific and environmental factors.

(4) Any potential basibiont may adapt to epibiosis in at least 3 ways: tolerance, avoidance and defense. These behavioral patterns, like the mechanisms within each category, may be combined. For a given species the resulting complex of adaptations may vary with season, latitude, habitat, individual age, physiological condition, biological cycles and tissue type.

Acknowledgements. I am particularly grateful to Jon Havenhand (Kristineberg, Sweden) for his pitiless and very constructive corrections of the English manuscript.

\section{LITERATURE CITED}

Absolom, D. R., Lamberti, F. V., Policova, Z., Zingg, W., van Oss, C. J., Newmann. A. W (1983). Surface thermodynamics of bacterial adhesion. Appl. envir. Microbiol. 46 (1): 90-97

Accorinti, J. (1983). Antifungal products from algal origin (Review). Rev. int. Océanogr. méd. 67: 45-53

Adamson, A. W. (1982). Physical chemistry of surfaces. WileyInterscience, New York

Baier, R. E. (1981). Early events of micro-biofouling of all heat transfer equipment. In: Somerscules, E. F. C., Knudsen, J. G. (eds.) Fouling of heat transfer equipment. Hemisphere Publ. Corp., Washington, p. 293-304

Baier, R. E. (1984). Initial events in microbial film formation. In: Costlow, J. D., Tipper, R. C. (eds.) Marine biodetermination: an interdisciplinary study. E. \& F. N. Spon Ltd., London, p. 57-62

Baier, R. E., Meyer, A. E., de Palma, V A., King, R. W. Fornalik, M. S. (1983). Surface microfouling during the induction period. J. Heat Transfer 105: 618-624
Baker, J. H., Orr, D. R. (1986). Distribution of epiphytic bacteria on freshwater plants. J. Ecol. 74: 155-165

Bakus, G. J., Kawaguchi, M. (1984). Toxins from marine organisms: studies on antifouling. In: Bolis et al. (eds.) Toxins, drugs and pollutants in marine animals. SpringerVerlag, Berlin, p. 43-46

Bakus, G. J., Targett, N. M. Schulte, B. (1986). Chemical ecology of marine organisms: an overview. J. chem. Ecol. 12 (5): 951-987

Ballentine, D. L. (1979). The distribution of algal epiphytes on macrophyte hosts offshore from La Parguera, Puerto Rico. Botanica mar. 22: 107-111

Barkai, A., McQuaid, C. (1988). Predator-prey role reversal in a marine benthic ecosystem. Science, N.Y 242: 62-64

Barnes, R. D. (1987). Invertebrate zoology, 5 th edn. Saunders College Publ., Philadelphia

Barthel, D., Wolfrath, B. (1989). Tissue sloughing in the sponge Halichondria panicea: a fouling organism prevents being fouled. Oecologia (Berl.) 78: 357-360

Bazzaz, F. A., Chiariello, N. R., Coley, P. D., Pitelka, L. F (1987). Allocating resources to reproduction and defense BioSci. 37 (1): 58-67

Bell, W. H., Lang, J. M., Mitchell, R. (1974). Selective stimulation of marine bacteria by algal extracellular products Limnol. Oceanogr. 19 (5): 833-839

Booth, W. E., Hoppe, H.-G. (1985). Epiphyte bacterial activity on different macroalgal species determined by tritiated thymidine incorporation. Botanica mar. 27: 47-56

Brancato, M. S., Woollacott, R. M. (1982). Effect of microbial films on settlement of bryozoan larvae (Bugula simplex; B. stolonifera, B. turrita). Mar. Biol. 71: 51-56

Breitburg, D. L. (1984). Residual effects of grazing: inhibition of competitor recruitment by encrusting coralline algae. Ecology 65 (4): 1136-1143

Brewer, R. H. (1984). The influence of the orientation, roughness and wettability of solid surfaces on the behavior and attachment of planulae of Cyanea (Cnidaria, Scyphozoa). Biol. Bull. mar biol. Lab., Woods Hole 166: $11-21$

Bronmark, C. (1985). Interactions between macrophytes, 
epiphytes and herbivores: an experimental approach. Oikos 45: 26-30

Brouns, J. J W M., Heijs, F. M. L. (1986). Production and biomass of the seagrass Anhalus acovoides (Lf) Royle and its epiphytes. Aquat. Bot. 25: 21-45

Bulthuis, D. A., Woelkerling, W. J. (1983). Biomass accumulation and shading effects of epiphytes on leaves of seagrass, Heterozostera tasmanica, in Victoria, Australia. Aquat. Bot. 16: 137-148

Busscher, H. J. (1985). Surface free energies and the adhesion of oral bacteria. Ph. D. thesis, Rijksuniversiteit te Groningen

Butman, C. A. (1987). Larval settlement of soft-sediment invertebrates: the spatial scales of pattern explained by active habitat selection and the emerging rôle of hydrodynamical processes. Oceanogr. mar. Biol. A. Rev. 25: $113-165$

Caccamese, S., Azzolini, R. (1979). Screening for antimicrobial activities in marine algae from Eastern Sicily. Planta Med. 37: 333-339

Caccamese, S., Azzolini, R., Fumari, G., Cormaci, M., Grasso, S. (1980). Antimicrobial and antiviral activities of extracts from Mediterranean algae. Botanica mar. 23: 285-288

Caccamese, S., Azzolini, R., Furnari, G., Cormaci, M., Grasso, S. (1981). Antimicrobial and antiviral activities of some marine algae from Eastern Sicily. Botanica mar. 24: 365-367

Caine, E. A. (1986). Carapace epibionts of nesting loggerhead sea turtles: Atlantic coast of USA. J. exp. mar. Biol. Ecol. 95: $15-26$

Cattaneo, A. (1983). Grazing on epiphytes. Limnol. Oceanogr. 28 (1): $124-132$

Cattaneo, A., Kalff, J. (1978). Seasonal changes of the epiphyte community of natural and artificial macrophytes in Lake Memphremagog (Que. \& Vt.). Hydrobiologia 60 (2): 135-144

Cattaneo, A., Kalff, J (1979). Primary production of algae growing on natural and artificial aquatic plants: a study of interactions between epiphytes and their substrate. Limnol. Oceanogr. 24 (6): 1031-1037

Chabot, R., Bourget, E. (1988). Influence of substratum heterogeneity and settled barnacle density on the settlement of cypris larvae. Mar. Biol. 97 -45-56

Characklis, W. G. (1981). Fouling biofilm development: a process analysis. Biotechnol. Bioengng 23: 1923-1960

Christie, A. O. (1973). Spore settlement in relation to fouling by enteromorpha. In: Acker, R. F., Brown, B. F., DePalma, J. R., Iverson, W P. (eds.) Proc. 3rd int. Cong. Mar Corr Foul., National Bureau Standards, Gaithersburg. Northwestern, Univ. Press, Evanston, p. 674-681

Christophersen, C. (1985). Secondary metabolites from marine bryozoans. A review. Acta Chem. scand. B 39: 517-529

Cimino. G., de Rosa. S., de Stefano, S., Morrone, R., Sodano, G. (1985). The chemical defense of nudibranch molluscs. Tetrahedron 41 (6): 1093-1.100

Coley, P. D. (1986). Costs and benefits of defense by tannins in a neotropical tree. Oecologia (Berl.) 70: 238-241

Coley, P. D., Bryant, J. P., Chapin, F S. (1985). Resource availability and plant antiherbivore defense. Science, N.Y 230: 895-899

Connell, J. H., Slatyer, R. O. (1977). Mechanisms of succession in natural communities and their role in community stability and organization. Am. Nat. 111: 1119-1144

Cooksey, B., Cooksey, K. E., Millar, C. A., Paul, J. H., Rubin, R., Webster, D. (1984). The attachment of microfouling diatoms. In: Costlow, J. D., Tipper, R. C. (eds.) Marine biodetermination: an interdisciplinary study. E. \& F. N. Spon Ltd, London, p. 167-172
Corpe, W. A. (1970). Attachment of manne bacteria to solid surfaces. In: Manly, R. S. (ed.) Adhesion in biological systems. Academic Press, London, p. 73-87

Corpe, W A. (1982). Microfouling: the role of primary film forming marine bacteria. Proc. 3rd int. Cong. Mar. Corr Foul. National Bureau Standards, Gaithersburg, USA, p. $598-609$

Corpe, W. A. (1982). Microbial attachment and growth on solid surfaces. Conf. Progr Chem. Disinfec. new concepts and materials, 1982, New York, p. 35-43

Corpe, W. A., Matsuuchi, L., Armbruster, B. (1976). Secretion of adhesive polymers and attachment of marine bacteria to surfaces: In: Sharpley, J. M., Kaplan, A. M. (eds.) Proc. 3rd int. biodeter. Symp. Applied Scientific Publishers, London, p. $433-442$

Costerton, J. W., Geesey, G. G., Cheng, K.-J. (1978). How bacteria stick. Sci. Am. 238: 86-95

Costlow, J. D., Tipper, R. C. (eds.) (1984). Marine biodeterioration: an interdisciplinary study. E. \& F. N. Spon Ltd., London

Crisp, D. J. (1974). Factors influencing the settlement of marine invertebrate larvae. In: Grant, P. T. Mackie, A. M. (eds.) Chemoreception in marine organisms. Academic Press, London, New York, p. 177-265

Crisp, D. J. (1984). Overview of research on marine invertebrate larvae, 1940-1980. In: Costlow, J. D., Tipper, R. C. (eds.) Marine biodeterioration: an interdisciplinary study. E. \& F. N. Spon Ltd., London, p. 103-1.26

Cuba, T. R., Blake, N. J. (1983). The initial development of a marine fouling assemblage on a natural substrate in a subtropical estuary. Botanica mar. 26: 259-264

Cuomo, Y., Vanzanella, F., Fresi, E., Cinelli, F., Mazzella, L. (1985). Fungal flora of Posidonia oceanica and its ecological significance. Trans. Br. mycol. Soc. 84 (1): 35-40

D Antonio, C. (1985). Epiphytes on the rocky intertidal red alga Rhodomela larix (Turner) C. Agardh: negative effects on the host and food for herbivores? J. exp. mar. Biol. Ecol. 86: $197-218$

Dexter, S. C. (1976). Influence of substrate wettability on the formation of bacterial slime films on solid surfaces immersed in natural sea water Proc. 4th int. Cong. Mar. Corr. Foul, Boulogne, France, 1977, p. 137-144

Dexter, S. C. (1978). Influence of substratum critical surface tension on bacterial adhesion - in situ studies. J. Colloid Interface Sci. 70: 346-354

Dexter, S. C., Lucas, K. E. (1985). The study of biofilm formation under water by photoacoustic spectroscopy. J. Colloid Interface Sci. 104 (1): 15-27

Dexter, S. C., Sullivan, J. D. Jr., Williams, J. III, Watson, S. W (1975). Influence of substrate wettability on the attachment of marine bacteria to various surfaces. Appl. Microbiol. 30 (2): $298-308$

Dixon, J., Schroeter, S. C., Kastendick, J. (1981). Effects of encrusting bryozoan, Membranipora membranacea, on the loss of blades and fronds by the giant kelp, Macrocystis pyrifera (Laminariales). J. Phycol. 17: 341-345

Douglas. L. J. (1985). Adhesion of pathogenic Candida species to host surfaces. Microbiol. Sci. 2 (8): 243-247

Dyrynda, P. E. J (1986). Defensive strategies of modular organisms. Phil. Trans. R. Soc. (Ser. B) 313: 227-243

Evans, L. V (1981). Marine algae and fouling: a review, with particular reference to ship-fouling. Botanica mar. 24 : $167-171$

Fagerström, T (1989). Antiherbivory chemical defense in plants: a note on the concept of cost. Am. Nat. 133 (2): $281-287$

Fattom, A., Shilo, M. (1984). Hydrophohicity as an adhesion 
mechanism of benthic cyanobacteria. Appl. envirl Microbiol. 47 (1): 135-143

Faulkner, D. J. (1984). Marine natural products: metabolites of marine algae and herbivorous marine molluscs. Nat. Product Rep. (Lond.) 1: 251-280

Faulkner, D. J. (1986). Marine natural products. Nat. Product Rep. (Lond.) 3: 1-33

Faulkner, D. J. (1987). Marine natural products, Nat. Product Rep. (Lond.) 4: 539-576

Feeny, P. (1976). Plant apparancy and chemical defense. Rec Adv. Phytochem. 10: 1-40

Feifarek, B. P. (1987). Spines and epibionts as antipredator defenses in the thorny oyster Spondylus americanus Hermann. J. exp. mar Biol. Ecol. 105: 39-56

Ferreira, S., Seeliger, U. (1985). The colonization process of algal epiphytes on Ruppia maritima L. Botanica mar. 28: 245-249

Filion-Myklebust, C., Norton, T. A. (1981). Epidermis shedding in the brown seaweed Ascophyllum nodosum (L.) Le Jolis, and its ecological significance. Mar. Biol. Lett. 2: 45-51

Fishlyn, D. A., Phillips, D. W. (1980). Chemical camouflaging and behavioral defense against a predatory seastar by three species of gastropods from the surf grass Phyllospadix Community. Biol. Bull. mar. biol. Lab., Woods Hole. 158: $34-48$

Fletcher, R. L., Baier, R. E. (1984). Influence of surface energy on the development of the green alga Enteromorpha. Mar. Biol. Lett. 5: 251-254

Fletcher, M., Baier, R. E., Fornalik, M. S. (1984). The influence of surface energy on spore development in some common marine fouling algae. 6th int. Cong. Mar Corr. Foul., Athens. Greece 1984, p. 129-144

Fletcher, M., Loeb, G. I. (1976). The influence of substratum surface properties on the attachment of a marine bacterium. In: Kerker, M. (ed.) Colloid and interface science. Vol. 3. Academic Press Inc., New York, p. 459-469

Fletcher, M., Loeb, G. I. (1979). Influence of substratum characteristics on the attachment of a marine pseudomonad to solid surfaces. Appl. envirl Microbiol. 37: 67-72

Fletcher, M., McEldowney, S. (1984). Microbial attachment to nonbiological surfaces. In: Klug, M. J., Reddy, C. A. (eds.) Current perspectives in microbial ecology. Proc. 3rd int. Symp. Microb. Ecol., Mich. State Univ.. 1983, p. 124-129

Gerhart, D. J., Rittschoff, D., Mayo, S. (1988). Chemical ecology and the search for marine antifoulants: studies of a predator-prey symbiosis. J. chem. Ecol. 14 (10): 1903-1915

Gerson, D. F. (1980). Cell surface energy, contact angles and phase partition. I. Lymphocytic cell lines in biphasic aqueous mixtures. Biochim. Biophys. Acta 602: 269-280

Gerson, D. F., Akit, J. (1980). Cell surface enrgy, contact angles and phase partition. II. Bacterial cells in biphasic aqueous mixtures. Biochim. Biophys. Acta 602: 281-284

Gerson, D. F., Scheer, D. (1980). Cell surface energy, contact angle and phase partition. III. Adhesion of bacterial cell to hydrophobic surfaces. Biochim. Biophys. Acta 602: 506-510

Goering, J. J., Parker, P. L. (1972). Nitrogen fixation by epiphytes on sea grasses. Limnol. Oceanogr. 17 (2): 320-323

Goupil, D. W., de Palma, V. A., Baier, R. E. (1973). Prospects for nontoxic fouling resistant paints. Proc. 9th Ann. Conf. Mar. Techn. Soc., Wash., p. 445-458

Goupil, D. W., de Palma, V A., Baier, R. E. (1980). Physical/ chemical characteristics of the macromolecular conditioning film in biological fouling. Proc. 5th int. Cong. Mar. Corr. Foul, Madrid. p. 401-410
Hadfield, M. G. (1986). Settlement and recruitment of marine invertebrates: a perspective and some proposals. Bull. mar. Sci. 39 (2): $418-425$

Harlin, M. M. (1973). Transfer of products between epiphytic marine algae and host plants. J. Phycol. 9: 243-248

Harlin, M. M. (1980). Seagrass epiphytes. In: Phillips, R. C., McRoy, C. P. (eds.) Handbook of seagrass biology: an ecosystem perspective. Jarland STPM Press, New York, p. $117-151$

Harrison, P. G. (1982). Control of microbial growth and of amphipod grazing by water-soluble compounds from leaves of Zostera marina. Mar. Biol. 67: 225-230

Harrison, P. G., Durance, C. D. (1985). Reductions in photosynthetic-carbon uptake in epiphytic diatoms by watersoluble extracts of leaves of Zostera marina. Mar. Biol. 90: $117-119$

Hay, M. E. (1986). Associational plant defenses and the maintenance of species diversity: turning competitors into accomplices. Am. Nat. 128 (5): 617-641

Holmes, P. E. (1986). Bacterial enhancement of vinyl fouling by algae. Appl. envirl Microbiol. 52 (6): 1391-1393

Horner, S. M. J. (1987). Similarity of epiphyte biomass distribution on Posidonia and artificial seagrass leaves. Aquat. Bot. 27 159-167

Huang, R., Boney, A. D. (1985). Individual and combined interactions between littoral diatoms and sporelings of red algae. J. exp. mar Biol. Ecol. 85: 101-111

Ingle, R. W (1983). Shallow water crabs. Synopses of the British fauna, No. 25. Cambridge Univ. Press, Cambridge

Jackson, J. B. C. (1977). Habitat area, colonisation and development of epifaunal community structure. In: Keegan, B. F., Ceidigh, P. O., Boaden, P. J. S. (eds.) Biology of benthic organisms. Pergamon Press, London, p. 349-358

Jagels, R. (1973). Studies of a marine grass, Thalassia testudinum I. Ultrastructure of the osmoregulatory leaf cells. Am. J. Bot. 60 (10): 1003-1009

Johnson, C. R., Mann, K. H. (1986a). The importance of plant defense abilities to the structure of subtidal seaweed communities: the kelp Laminaria longicruris de la Pylaie survives grazing by the snail Lacuna vincta (Montagu) at high population densities. J. exp. mar. Biol. Ecol. 97: 231-267

Johnson, C. R, Mann, K. H. (1986b). The crustose coralline alga, Phymatolithon foslie inhibits the overgrowth of seaweeds without relying on herbivores. J. exp. mar. Biol. Ecol. 96: 127-146

Kairesalo, T., Koskimies, I. (1987). Grazing by oligochaetes and snails on epiphytes. Freshwat. Biol. 17: 317-324

Keifer, P. A., Rinehart, K. L. Jr (1986). Renillafoulins, antifouling diterpenes from the sea pansy Renilla reniformis (Octocorallia). J. org. Chem. 51: 4450-4454

Keough, M. J. (1984). Dynamics of the epifauna of the bivalve Pinna bicolor: interactions among recruitment, predation, and competition. Ecology 65 (3): 677-688

Keough, M. J. (1986). The distribution of a bryozoan on seagrass blades: settlement, growth and mortality. Ecology 67 (4): 846-857

Kirchman, D., Mitchell, R. (1981). A biochemical mechanism for marine biofouling. Oceans $7: 637-641$

Kirchman, D., Graham, S., Reish, D., Mitchell, R. (1982). Lectins may mediate in the settlement and metamorphosis of Janua (Dexiospira) brasiliensis Grube (Polychaeta: Spirorbidae). Mar. Biol. Lett. 3: 131-142

Kitamura, H., Hiroyama, K. (1987). Effects of primary films on the settlement of larvae of a bryozoan Bugula neritina. Nippon Suisan Gakk. 53 (8): 1377-1381

Kong, M. K., Chan, K. Y (1979). A study on the bacterial flora isolated from marine algae. Botanica mar. 22: 83--97 
Krupp, D. A. (1985). An immunochemical study of the mucus from the solitary coral Fungia scutoria (Scleractinia: Fungiidae). Bull. mar Sci. 36 (1) 163-176

Laihonen, P. Furman, E. R. (1986). The site of settlement indicates commensalism between bluemussel and its epibiont. Oecologia (Berl.) 71: 38-40

Larsson, S. Wiren, A., Lundgren, L, Ericsson, T. (1986). Effects of light and nutrient stress on leaf phenolic chemistry in Salix dasyclados and susceptibility to Galerucella lineola (Coleoptera). Oikos 47: 205-210

Lavenda, B. H. (1985), Brownian motion. Am. Scient. 252 (2): $56-67$

Lewis, T E., Garland, C. D., McMeekin, T A. (1985). The bacterial biota on crustose (nonarticulated) coralline algae from Tasmanian waters. Microb. Ecol. 11. 221-230

Libes, M. (1986). Productivity-irradiance relationship of Posidonia oceanica and its epiphytes. Aquat. Bot. 26 : 285-306

Linskens, H. (1963a). Beitrag zur Frage der Beziehung zwischen Epiphyt und Basiphyt bei marinen Algen. Pubbl, Staz. zool. Napoli 33: 274-293

Linskens, H. F. (1963b). Oberflächenspannung an marinen Algen. Proc. K. ned. Akad. Wet. (Sect. C) 66: 205-217

Little, B. J. (1984). Succession in microfouling. In: Costlow, J. D., Tipper, R. C. (eds.) Marine biodeterioration: an interdisciplinary study. E. \& F. N. Spon Ltd, London, p. 63-67

Lupton, F. S., Marshall, K. C. (1984). Mechanisms of specific bacterial adhesion to cyanobacterial heterocysts. In: Klug. M. J., Reddy, C. A. (eds.) Current perspectives in microbial ecology. Proc. 3rd int. Symp. Microb. Ecol, Mich. State Univ., 1983, p. $144-150$

Lüttge, U. (1985). Epiphyten: Evolution und Ökophysiologie Naturwissenschaften 72: 557-566

Lynch, J. M., Fletcher, M., Latham, M. J. (1979). Biological interactions. In: Lynch, J. M., Poole, N. J. (eds.) Microbial ecology: a conceptual approach. Blackwell Scientific Publishing, Oxford, p. 171-187

Maiorana, V. C. (1979). Nontoxic toxins: the energetics of coevolution. Biol. J. Linn. Soc. 11 387-396

Maki, J. S., Rittschof, D., Costlow, J. D., Mitchell, R. (1988). Inhibition of attachment of larval barnacles, Balanus amphitrite, by bacterial films. Mar. Biol. 97: 199-206

Marshall, K. C. (1972). Mechanisms of adhesion of marine bacteria to surfaces. Proc. 3rd int. Cong. Mar. Corr Foul National Bureau Standards, Gaithersburg, USA p. $625-632$

Marshall, K. C., Stout, R., Mitchell, R. (1971.). Mechanisms of the initial events in the sorption of marine bacteria to surfaces. J. gen. Microbiol. 68: 337-348

Mazure, H. G. F., Field, J. G. (1980). Density and ecological importance of bacteria on kelp fronds in an upwelling region. J exp mar. Biol Ecol 43: 176-182

Meadows, P. S., Williams, G. B. (1963). Settlement of Spirorbis borealis Daudin larvae on surfaces beanng films of microorganisms. Nature, Lond 198: 610-611

Mihm, J. W., Banta, W. C., Loeb, G. I. (1981). Effects of adsorbed organic and primary fouling films on bryozoan settlement. J. exp. mar. Biol. Ecol. 54: 167-179

Mitchell, R., Kirchman, D. (1984) The microbial ecology of marine surfaces. In: Costlow, J. D., Tipper, R. C. (eds.) Marine biodeterioration: an interdisciplinary study. E. \& F N. Spon Ltd., London, p. 49-58

Morse, D. E. (1984). Biochemical control of larval recruitment and marine fouling. In: Costlow, J. D., Tipper, R. C. (eds.) Marine biodeteration: an interdisciplinary study. E. \& F. N Spon Ltd., London, p. 134-140

Moss, B. L. (1982). The control of epiphytes by Halidrys siliquosa (L.) Lyngb. (Phaeophyta: Cystoseiraceae). Phy cologia 21 (2): 185-191

Novak, R. (1984). A study in ultra-ecology: microorganisms on the seagrass Posidonia oceanica (L.) Delile. P.S.Z.N.I Mar Ecol. 5 (2): 143-190

O'Neill, T B., Wilcox, G. L. (1971). The formation of a 'Primary Film' on material submerged in the sea at Port Hueneme California. Pacif. Sci. 25: 1-12

Osman, R. W. (1977). The establishment and development of a marine epifaunal community. Ecol. Monogr. 47. 37-63

Ostrofsky, M. L., Zettler, E. R. (1986). Chemical defenses in aquatic plants. J. Ecol. 74: 279-287

Oswald, R. C., Seed, R. (1986). Organisation and seasonal progression within the epifaunal communities of coastal macroalgae. Cah. Biol. mar. 27: 29-40

Oswald, R. C., Telford, N., Seed, R., Happey-Wood, C. M. (1984). The effect of encrusting bryozoans on the photosynthetic activity of Fucus serratus L. Estuar. Cstl Shelf Sci. 19: $697-702$

Parry, D. L. (1984). Chemical properties of the test of ascidians in relation to predation. Mar Ecol. Prog. Ser. 17: 279-282

Paul, J. H., Jeffrey, W. H. (1985). Evidence for seperate adhesion mechanisms for hydrophilic and hydrophobic surfaces in Vibrio proteolytica. Appl. envirl Microbiol. 50 (2): $431-437$

Paul, V. J., van Alstyne, K. L. (1988). Chemical defense and chemical variation in some tropical Pacific species of Halimeda (Halimedaceae: Chlorophyta). Coral Reefs 6: 263-269

Penhale, P. A. (1977). Macrophyte-epiphyte biomass and productivity in an eelgrass (Zostera marina L.) community. J exp. mar. Biol. Ecol. 26: 211-224

Penhale, P. A., Smith, W. O. (1977). Excretion of dissolved organic carbon by eelgrass (Zostera marina) and its epiphytes. Limnol. Oceanogr. 22 (3): 400-407

Pesando, D., Caram, B. (1984). Screening of marine algae from the French Mediterranean coast for antibacterial and antifungal activity. Botanica mar. 27: 381-386

Pesando, D., Gnassia-Barelli, M., Gueho, E. (1979). Antifungal properties of some marine planktonic algae. In: Hoppe, $\mathrm{H}$ A., Levring, T., Tanaka, Y (eds.) Marine algae in pharmaceutical science, Walter de Gruyter, Berlin, p. 461-472

Pringle, J. H., Fletcher, M. (1983). Influence of substratum wettability on attachment of freshwater bacteria to solid surfaces. Appl. envrl Microbiol. 45 (3): 811-817

Riedl, R. (1971). Water movement: animals. In: Kinne, O. (ed.) Marine ecology. Wiley-Interscience, London, p. 1123-1156

Rittschoff, D. Hooper, I. R., Branscomb, E. S., Costlow, J. D. (1985). Inhibition of barnacle settlement and behavior by natural products from whip corals, Leptogorgia virgulata (Lamarck, 1815). J. chem. Ecol. 11 (5): 551-563

Rittschof, D., Hooper, I. R., Costlow, J D. (1986). Barnacle settlement inhibitors from sea pansies, Renilla reniformis. Bull. mar Sci. 39 (2) : 376-382

Rosenberg, M. (1981\}. Bacterial adherence to polysterene: a replica method of screening for bacterial hydrophobicity. Appl. envirl Microbiol. 42 (2): 375-377

Rosenberg, M. (1984). Bacterial adherence to hydrocarbons: a useful technique for studying cell surface hydrophobicity. Fedn Eur Microbiol. Soc. (FEMS) Microbiol. Lett. 22: 289-295

Rosenberg, M., Gutnik, D., Rosenberg, E. (1980). Adherence of bacteria to hydrocarbons: a simple method for measuring cell surface hyctrophobicity. Fedin Eur. Microbiol. Soc. (FEMS) Microbiol. Lett. 9:29-33

Russeil, G. (1983). Parallel growth patterns in algal epiphytes and laminaria blades. Mar. Ecol. Prog. Ser. 13: 303-304 
Russell, G., Veltkamp, V. J. (1984). Epiphyte survival on skinshedding macrophytes. Mar. Prog. Ser. 18: 149-153

Ryland, J. S. (1974). Observations on some epibionts of gulf weed, Sargassum natans (L.) Meyen. J. exp. mar. Biol. Ecol. 14: 17-25

Sand-Jensen, K. (1977). Effect of epiphytes on eelgrass photosynthesis. Aquat. Bot. 3: 55-63

Sand-Jensen, K., Revsbech, N. P. (1987). Photosynthesis and light adaptation in epiphyte-macrophyte associations measured by oxygen microelectrodes. Limnol. Oceanogr. 32 (2): $452-457$

Sar, N., Rosenberg, E. (1987). Fish skin bacteria: colonial and cellular hydrophobicity. Microb. Ecol. 13: 193-202

Saroyan, J. R. (1988). Marine biology in antifouling paints. J. Paint Technol. 41 (531): 285-303

Sieburth, J. McN., Conover, J. T. (1965). Sargassum tannin, an antibiotic which retards fouling. Nature, Lond. 208: 52-53

Sieburth, J. McN., Tootle, J. L. (1981). Seasonality of microbial fouling on Ascophyllum nodosum (L.) Lejol, Fucus vesiculosus L., Polysiphonia lanosa (L.) Tandy and Chondrus crispus Stackh. J. Phycol. 17: 57-64

Stoecker, D. (1978). Resistance of a tunicate to fouling. Biol. Bull. mar. biol. Lab., Woods Hole 155: 615-626

Stoecker, D. (1980). Relationship between chemical defense and ecology of benthic ascidians. Mar. Ecol. Prog. Ser. 3: $257-265$

Sutherland, J. P. (1974). Multiple stable points in natural communities. Am. Nat. 108: 859-873

Sutherland, J. P., Karlson, R. H. (1977). Development and stability of the fouling community at Beaufort, North Carolina. Ecol. Monogr. 47: 425-446

Targett, N. M., Bishop, S. S., McConnell, O. J., Yoder, J. A (1983). Antifouling agents against the benthic marine diatom Navicula salinicola: homarine from the gorgonians Leptogorgia virgulata and $L$. setacea and analogs. J. chem Ecol. $9(7): 817-829$

This review was submitted to the editor
Terry, L. A., Edyvean, R. G. J. (1981). Microalgae and corrosion. Botanica mar. 24: 177-183

Tosteson, T R., Corpe, W. A. (1975). Enhancement of adhesion of the marine Chlorella vulgaris to glass. Can. J. Microbiol. 21: 1025-1031

Tosteson, T. R., Revuelta, R., Zaidi, B. R., Imam, S. H., Bard, R F. (1983). Aggregation-adhesion enhancing macromolecules and the specificity of marine microbial surface interactions. J. Colloid Interface Sci. 104 (1): 60-71

van Alstyne, K. L. (1988). Herbivore grazing increases polyphenolic defenses in the intertidal brown alga Fucus distichus. Ecology 69 (3): 655-663

Wahl, M. (1987). Marine Epibiosis und Antifouling. Ph. D. thesis, Univ. Kiel

Walt, D. R., Smulow, J. B., Turesky, S. S., Hill, R. G. (1985) The effect of gravity on initial microbial adhesion. J. Colloid Interface Sci. 107 (2): 334-336

Wethey, D. S. (1986). Ranking of settlement cues by barnacle larvae: influence of surface contour. Bull. mar. Sci. 39 (2): $393-400$

Wicken, A. J. (1985). Bacterial cell walls and surfaces. In: Savag, D. C., Fletcher, M. (eds.) Bacterial adhesion. Plenum Publishing Corp., New York, p. 45-70

Wicksten, M. K. (1983). Camouflage in marine invertebrates. Oceanogr. mar. Biol. A. Rev. 21: 177-193

Winston, J. E. (1984). Why bryozoans have avicularia - a review of the evidence. Am. Mus. Novit. 2789: 1-26

Witman, J. D., Suchanek, T. H. (1984). Mussels in flow: drag and dislodgement by epizoans. Mar. Ecol. Prog. Ser. 16: 259-268

Woollacott, R. M. (1984). Environmental factors in bryozoan settlement. In: Costlow: J. D., Tipper, R. C. (eds.) Marine biodeterioration: an interdisciplinary study. E. \& F. N. Spon Ltd., London, p. 149-154

Young, C. M. (1986). Defenses and refuges: alternative mechanisms of coexistence between a predatory gastropod and its ascidian prey. Mar. Biol. 91: 513-522

Manuscript first received: February 16, 1989

Revised version accepted: September 6, 1989 